\title{
Role of Taurine, Oxygen Therapy and their Mixture as Anti-cancer Agents on the N-nitrosodiethylamine (NED) Induced Cancer in Male Adult Rats
}

\author{
Mohamed, I.A. Heibashy and Walaa, A.M. El-Nahrawy* \\ Department of Biological Application, Nuclear Research Center, \\ Atomic Energy Authority \\ * Zoology Department, Women's Collage, Ain Shams University
}

\begin{abstract}
The present investigation was conducted to elucidate the effects of taurine or oxygen molecules (Aquagen) or their mixture as anticancer agents in rats which were injected with $N$-nitrosodiethylamine (NED) in the presence of phenobarbital to promote cancer induction. As a result of cancer induction, serum tumor markers [Carcino-embryonic antigen (CEA), alpha-fetoprotein (AFP) and cancer antigen 19.9 $\left.\left(C A_{19.9}\right)\right]$ were significantly elevated. On the other hand, glutathione (GSH) content and glutathione peroxidase $\left(G p_{X}\right)$ activity were decreased significantly in blood, liver, stomach and intestine. Liver superoxide dismutase (SOD), catalase (CAT) and cytochrome $P_{450}$ activities were also decreased in the cancer group of rats in comparison to the control group. The administration of taurine or oxygen molecules (Aquagen) improved all these alterations and the maximum ameliorating effects were exhibited in the rats treated with the mixture of the anti-oxidant agents. The results of this worke suggested that taurine or oxygen molecules (Aquagen) has an appreciable anti-cancer efficacy.
\end{abstract}

\section{INTRODUCTION}

Cancer is a great problem face man. Cancer is a complex family of disease. It is a large group disease, may vary in age of onset, rate of growth, state of cellular differentiation, diagnostic detectability, invasiveness, metastatic potential, response to treatment and $\operatorname{prognosis}^{(1)}$. In terms of molecular and cell biology, however, cancer may represent a relatively small number of diseases caused by similar defects in cell function and resulting from similar alterations to cell's genes. So, cancer is a disease of abnormal gene expression. such altered gene expression occurs through a number of mechanisms, including, direct strike to DNA (such as gene mutations, translocations, or amplification) and abnormal gene transcription or translation ${ }^{(2)}$.

Numerous epidemiological studies have indicated that cancer is a disease of individuals with excessive exposure to tobacco, excessive consumption of fat and excessive exposure to genotoxic chemicals due to chronic infection or as a result of surrounding environment ${ }^{(3,4)}$. A common features among the majority of these agents is that they are 
producing free radicals that have an affinity to cause DNA damage by interacting with the relatively electron-rich bases in $\mathrm{DNA}^{(3)}$.

Nitroso-compounds are potent carcinogens detected in foodstuffs. The importance of dietary nitrosamines in relation to human cancer development is uncertain. Some investigators have studied the relationship between intakes of nitroso-compounds and risk of hepatogastro-intestinal cancer in different species of animals $^{(\mathbf{5 , 6 , 7 , 8 , 9})}$.

Hepatogastrointestinal carcinoma induced by the administration of $\mathrm{N}$ nitroso-diethylamine (NED) in rats showed similarities to human tumors and is, therefore, an ideal model for the investigation of cancer development and intervention by chemopreventive antioxidant agents $^{(5,10)}$.

Taurine (beta-amino-ethane sulphonic acid) is the most abundant intracellular free amino acid in the human body. It is distributed in many tissues, not incorported into proteins but found mainly in the free form. Taurine plays a vital role in many physiological events, including osmoregulation $^{(\mathbf{1 2})}$, detoxification, membrane stabilization ${ }^{(\mathbf{1 3})}$, neuromodulation $^{(\mathbf{1 4})}$, retinal and cardiac functions ${ }^{(\mathbf{1 5 )}}$. Taurine has also been implicated in the immune and inflammatory responses through its antioxidant ability as well as through its capacity to modulate myeloperoxidase activity and antimicrobial function in leucocytes $^{(\mathbf{1 6})}$.

Early studies have demonstrated that the treatment of cancer-induced rats with $1000 \mathrm{mg}$ taurine/kg b.wt for
30 and 60 days led to a significant amelioration in tumor markers (AFP, CEA, CA 19.9 and CA 72.4). Also, the author found an improvement in liver glutathione levels and glutathione peroxidase activity after taurine administration compared with cancer-induced rats. On the other hand, the author found a decline in lipid peroxidation of taurine treated rats after 30 and 60 days of treatment and the decline increased with the progress of time ${ }^{(7)}$.

In the treatment of cancer, conventional medicine includes surgery, chemotherapy, and radiation. By contrast, alternative therapy includes nutritional supplements, enzymes, diet, detoxification, electro medicine, oxygen therapy, change in life style, stress control, prevention, and more. The best alternative therapy depends on the nature of cancer.

Cancer victims have low oxygen levels throughout the body. Oxygen molecules (Aquagen) is involved in all life's vital processes, and for the proper of immune system function. The cells in the body that fight infection (granulocytes) produce hydrogen peroxide as a first line of defense against invading organisms like parasites, viruses, bacteria and yeast. It is also required for the metabolism of protein, carbohydrates, fats, vitamins and minerals ${ }^{(\mathbf{1 8}, 19)}$.

Furthermore, cultured cells of different carcinoma types were compared with non-cancerous human lung fibroblasts on exposure to ozonated air $(0.3,0.5$, and $0.8 \mathrm{ppm}$ of $\mathrm{O}_{3}$ for 8 days). Alveolar (lung) adenocarcinoma, breast adenocarcinoma, uterine carcinosarcoma and endometrial carcinoma showed 
$40 \%$ cell growth inhibition at $0.3 \mathrm{ppm}$ and $60 \%$ at $0.5 \mathrm{ppm}$. The noncancerous lung cells were unaffected at these levels. In $0.8 \mathrm{ppm}$ exposure, cancer cell growth inhibition was $90 \%$. Interestingly, at this level the control cell group started to manifest anabolic slowdown (50\%). The authors postulate that cancer cells are less able to compensate for the oxidative challenge of ozone than normal cells, possibly by a defective functional glutathione system ${ }^{(\mathbf{2 0})}$.

Moreover, oxygen therapy has been shown to be beneficial to patients with ischemic disorders, particularly of the lower limbs ${ }^{(21)}$. Also, ozone therapy increases oxygenation in the most poorlyoxygenated tissues of the anterior tibialis muscles and that oxygenation in these muscles might be related to tumor oxygenation ${ }^{(19)}$.

\section{MATERIAL \& METHODS}

Male albino rats (age 8 weeks) were obtained from the animal house of Nuclear Research Center, Inshas. Animals were then divided into five groups, a control and four experimental groups, each of 10 rats. All animals were fed on a standard rodent $\operatorname{diet}^{(\mathbf{2 2})}$. Fresh tap water was available all the time.

Induction of cancer by Nnitrosodiethylamine (NED):

Hepato-gastrointestinal

carcinoma was induced with a single intraperitoneal injection of NED (Sigma Chem. Co., St Louis, Mo. U.S.A.) with a dose of $200 \mathrm{mg} / 100 \mathrm{~g}$ body weight in saline at two months of age. Two weeks after administration of NED the carcinogenic effect was promoted by phenobarbital (0.05 \% PB Sigma Chem. Co., St Louis, Mo. U.S.A.). Promoter was incorporated into the rat chow for up to ten consecutive weeks $^{(23)}$.

After induction of cancer, the first experimental rat group (rats with induced hepato-gastrointestinal carcinoma, [HGC rats]) was not further treated and was referred to as HGC group. The $2^{\text {nd }}$ experimental group was injected intraperitonealy with $500 \mathrm{mg}$ taurine (Sigma Chem. Co., St Louis, Mo. U.S.A.) as a suspension in $10 \%$ sucrose solution/100 g body weight/day for one month and was referred to as $\mathrm{HGC}+\mathrm{T}$. The $3^{\text {rd }}$ experimental group was treated daily with $0.5 \mathrm{ml}$ oxygen molecules solution (Aquagen) (Sigma for Al Esraa Co.,U.S.A.)/100 g body weight for one month $(\mathrm{HGC}+\mathrm{O} 3$ group). The last experimental group received a mixture of taurine or Ozonated water at the same dose levels and periods as described previously and was referred to as $\mathrm{HGC}+\mathrm{T} \& \mathrm{O} 3$ group.

At the end of the experimental period, animals were scarified and blood was collected in heparinzed tube for determination of glutathione (GSH) and glutathione peroxidase $\left(G p_{X}\right)$. Another portion of blood was collected in a clean dry tube to obtain serum for determination of the tumor markers CEA, AFP and $\mathrm{CA}_{19.9}$. Biopsy samples of liver, stomach and intestine were taken quickly on an ice cold plate for the following measurements

Tumor markers estimation:

Serum carcino-embryonic antigen (CEA), alpha-fetoprotein (AFP) and 
the cancer antigen $\left(\mathrm{CA}_{19.9}\right)$ were assayed by radioimmunoassay (RIA) kits using solid phase component system. (ICN Pharmaceuticals Inc, USA).

\section{Markers of oxidative stress:}

The non-enzymatic antioxidant $\mathrm{GSH}^{(24)}$ and the activities of glutathione peroxidase ${ }^{(25)}$ were determined. Superoxide dismutase (SOD) activity was measured according to the method of Oyanagui $^{(26)}$ by the inhibition of nitric reduction rate by $50 \%$ with superoxide anions generated by xanthine/xanthine oxidase system. The reaction was monitored at $550 \mathrm{~nm}$ light absorbance. One activity unit (50\% inhibition) was expressed as NU (nitrite unit) $1 \mathrm{mg}$ protein/30min. Catalase was estimated colorimetrically by the method of $\operatorname{Sinha}^{(27)}$.

Lipid peroxidation as thiobarbituric acid reactive substances (TBARS) was measured by the method of Hogberg ${ }^{(28)}$ and Devasagayam $^{(29)}$.

Determination of cytochrom $\mathbf{P}_{450}$ level:

The level of $\mathrm{P}_{450}$ in 5-9 fractions was determined according to the modified method for measurement of $\mathrm{P}_{450}$ content of liver homogenates ${ }^{(\mathbf{3 0})}$.

Rats after scarified, livers were removed aseptically, washed with ice -cold sterile $0.15 \mathrm{M} \mathrm{KCl}$ and then homogenized in 3 volumes of the same solution in a Potter-Elvehjem homogenizer using a Teflon pestle. The homogenates were centrifuged at $9000 \mathrm{~g}$ for $20 \mathrm{~min}$ at $4^{\circ} \mathrm{C}$ and the supernatants (5-9) were filtered through sterile glass wool, immediately frozen in liquid nitrogen and kept at $-20^{\circ} \mathrm{C}$ pending analysis.

Briefly, the 5 - 9 fraction was diluted to $2-4 \mathrm{mg} / \mathrm{ml}$ with $0.1 \mathrm{M}$ potassium phosphate $\mathrm{pH}(7.0)$. The suspension was gassed with carbon monoxide (CO) for one minute, transferred to both reference and sample cuvettes and then allowed for baseline correction between $390-490$ $\mathrm{nm}$ for $3 \mathrm{~min}$. Then, a small amount of sodium dithionite was added to the content in the sample cuvette and the resulting dithionite-reduced difference spectrum was recorded between 390 - $490 \mathrm{~nm} 2$ min later.

Using that method with the crude microsomal or 5-9 fractions, the $\mathrm{P}_{450}$ peak was clearly separated from cytochrome peak at $424 \mathrm{~nm}$ which then enabled calculation the net absorbance between 450 and $490 \mathrm{~nm}$. The concentration of $\mathrm{P}_{450}$ was calculated using the molar extinction coefficient of $91 \mathrm{mM}^{-1} \mathrm{~cm}^{-1}$.

Data were statistically analyzed using analysis of variance (ANOVA) followed by Duncan's multiple range test according to Snedecor and Cochran ${ }^{(31)}$.

\section{RESULT}

\section{Serum tumor markers and blood GSH and $G p_{X}$ :}

The results presented in table (1) show that there was a significant increase in the three studied serum tumor markers, CEA, AFP and $\mathrm{CA}_{19.9}$ in rats with hepatogastrointestinal carcinoma induced by Nnitrosodiethylamine administration. Rats treated with either taurine or ozone or their mixture for one month exhibited levels higher than that of the 
control animals, but less than that of the HGC group. The lowest levels of serum tumor markers were always exhibited by the groups treated with taurine or ozone.

Similarly, blood glutathione content and glutathione peroxidase activities were significantly lower in the HGC group, in the HGC rats treated with taurine, in the HGC animals treated with ozone and in the HGC group treated with the mixture of taurine and ozone as compared with the corresponding control values. However, in all cases the treatment with taurine ozone or their mixture significantly elevated GSH content and $\mathrm{GP}_{\mathrm{X}}$ activity above the levels exhibited by the HGC group.

Markers of oxidative stress in liver:

Data in table (2) reveal that there was a significant decrease in the activities of liver GSH, Gp $p_{X}$, SOD and catalase in the HGC animals as compared with their corresponding control values. Treatment with taurine or ozone or their mixture significantly enhanced these enzymatic levels. On the other hand, statistical analysis showed that there was a significant increase in the liver lipid peroxidation (TBARS) in comparison with the control value in all cancer bearing rats (table 2). Moreover, in HGC rats and in the groups supplemented with taurine or oxygen molecules (Aquagen) or their mixture, there was a significant decrease in the level of liver cytochrome $\mathrm{P}_{450}$ as compared with the corresponding value of control rats. Treatment taurine or oxygen molecules (Aquagen) or their mixture significantly ameliorated cytochrome $\mathrm{P}_{450}$ activity, but did not bring it back to the control level.

Stomach oxidative stress profile:

Table 3 shows that the activities of $\mathrm{GSH}$ and $\mathrm{Gp}_{\mathrm{X}}$ of stomach was significantly lower than the control values in all experimental groups. On the contrary, there was a significant elevation in the activities of stomach $\mathrm{TBAR}_{\mathrm{S}}$ as a result of cancer induction. These cancer-induced elevation in the activities of stomach TBAR $_{S}$ decreased significantly after the HGC rats were treated with taurine or ozone or their mixture for one month. However, the levels of stomach $\mathrm{TBAR}_{\mathrm{S}}$ in the experimental rats were still higher than the control value.

Intestinal oxidative stress profile:

A significant decline in the intestinal GSH content and $\mathrm{Gp}_{\mathrm{X}}$ activities were observed in the HGC rats and also in those treated with taurine or ozone or their mixture (table 3). There was a significant increase in the activities of intestinal $\mathrm{TBAR}_{\mathrm{S}}$ in the HGC group in comparison with the corresponding control value (table 3 ). Administration of taurine or oxygen molecules (Aquagen) or their mixture significantly lowered the $\mathrm{TBAR}_{\mathrm{S}}$ below that of the $\mathrm{HGC}$, but did not bring it back to the control level. 
Table (1): Effects of taurine, oxygen molecules (Aquagen) and their mixture on serum CEA, AFP and $\mathrm{CA}_{19.9}$ as well as blood GSH content and $\mathrm{Gp}_{\mathrm{X}}$ activity in rats with induced HGC

\begin{tabular}{|l|c|c|c|c|c|}
\hline \multirow{2}{*}{ Groups } & \multicolumn{3}{|c|}{ Serum tumor markers } & \multicolumn{2}{c|}{ Blood } \\
\cline { 2 - 6 } & $\begin{array}{c}\text { CEA } \\
(\mathrm{ng} / \mathrm{ml})\end{array}$ & $\begin{array}{c}\text { AFP } \\
(\mathrm{ng} / \mathrm{ml})\end{array}$ & $\begin{array}{c}\mathbf{C A}_{19.9} \\
(\mathrm{U} / \mathrm{L})\end{array}$ & $\begin{array}{c}\text { GSH } \\
(\mathrm{mg} / \mathrm{dl})\end{array}$ & $\begin{array}{c}\text { Gpx } \\
(\mu \mathrm{mol} \text { of } \\
\text { GSH } \\
\text { oxidized/mi } \\
\mathrm{n} / \mathrm{mg} \mathrm{Hb})\end{array}$ \\
\hline Control & $0.18 \pm 0.06^{\mathbf{a}}$ & $0.82 \pm 0.11^{\mathbf{a}}$ & $6.05 \pm 1.05^{\mathbf{a}}$ & $2.11 \pm 0.11^{\mathbf{a}}$ & $12.54 \pm 0.77^{\mathbf{a}}$ \\
\hline HGC & $7.55 \pm 0.32^{\mathbf{b}}$ & $21.11 \pm 2.04^{\mathbf{b}}$ & $47.23 \pm 4.22^{\mathbf{b}}$ & $1.03 \pm 0.15^{\mathbf{b}}$ & $5.47 \pm 1.21^{\mathbf{b}}$ \\
\hline HGC + T & $3.09 \pm 0.24^{\mathbf{c}}$ & $10.23 \pm 1.67^{\mathbf{c}}$ & $29.54 \pm 3.41^{\mathbf{c}}$ & $1.66 \pm 0.16^{\mathbf{c}}$ & $8.21 \pm 1.59^{\mathbf{c}}$ \\
\hline HGC + O3 & $3.45 \pm 0.28^{\mathbf{d}}$ & $12.89 \pm 1.23^{\mathbf{d}}$ & $36.68 \pm 3.71^{\mathbf{d}}$ & $1.41 \pm 0.14^{\mathbf{d}}$ & $7.18 \pm 1.91^{\mathbf{d}}$ \\
\hline HGC + T + O3 & $2.23 \pm 0.17^{\mathbf{e}}$ & $8.603 \pm 1.05^{\mathbf{e}}$ & $21.93 \pm 2.74^{\mathbf{e}}$ & $1.93 \pm 0.18^{\mathbf{e}}$ & $10.08 \pm 1.35^{\mathbf{e}}$ \\
\hline
\end{tabular}

Table (2): Effects of taurine, oxygen molecules (Aquagen) and their mixture on liver activities of $\mathrm{Gp}_{\mathrm{X}}$, SOD, CAT, cytochrome $\mathrm{P}_{450}$ and liver contents of GSH, TBAR $\mathrm{S}$ and in rats with induced HGC

\begin{tabular}{|c|c|c|c|c|c|c|}
\hline \multirow[b]{2}{*}{ Groups } & \multicolumn{6}{|c|}{ Liver } \\
\hline & $\begin{array}{c}\text { GSH } \\
\mathrm{mg} / \mathrm{g} \\
\text { tissue }\end{array}$ & $\begin{array}{c}\text { Gpx } \\
\mu \mathrm{mol} / \mathrm{min} \\
/ \mathrm{g} \text { protein }\end{array}$ & $\begin{array}{c}\text { SOD } \\
\mathrm{NU} / 60 \\
\mathrm{~min} / \mathrm{mg} \\
\text { protein }\end{array}$ & $\begin{array}{c}\text { CAT } \\
\mu \mathrm{mol} / 60 \\
\mathrm{~min} / \mathrm{mg} \\
\text { protein }\end{array}$ & $\begin{array}{c}\mathbf{T B A R}_{\mathbf{S}} \\
\mathrm{nmol} / 100 \\
\mathrm{mg} \\
\text { protein }\end{array}$ & $\begin{array}{c}\text { Cytochro } \\
\text { me } \mathbf{P}_{450} \\
\text { reductase } \\
\text { activity } \\
\text { nmol/min/ } \\
\text { mg protein }\end{array}$ \\
\hline Control & $\begin{array}{l}20.23 \pm \\
0.86^{\mathrm{a}}\end{array}$ & $\begin{array}{l}93.45 \pm \\
2.22^{\mathrm{a}}\end{array}$ & $\begin{array}{l}7.67 \pm \\
0.45^{\mathrm{a}}\end{array}$ & $\begin{array}{l}60.98 \pm \\
1.78^{a}\end{array}$ & $\begin{array}{l}2.11^{ \pm} \\
0.19^{a}\end{array}$ & $\begin{array}{l}0.069 \pm \\
0.011^{\mathrm{a}}\end{array}$ \\
\hline HGC & $\begin{array}{l}9.51 \pm \\
0.53^{\mathbf{b}}\end{array}$ & $\begin{array}{l}38.32 \pm \\
1.16^{\mathbf{b}}\end{array}$ & $\begin{array}{l}.18 \pm \\
0.31^{\mathbf{b}}\end{array}$ & $\begin{array}{l}42.26 \pm \\
1.32^{\mathbf{b}}\end{array}$ & $\begin{array}{l}3.67 \pm \\
0.24^{\mathbf{b}}\end{array}$ & $\begin{array}{l}0.042^{ \pm} \\
0.015^{\text {b }}\end{array}$ \\
\hline $\mathrm{HGC}+\mathrm{T}$ & $\begin{array}{l}15.65 \pm \\
0.73^{c}\end{array}$ & $\begin{array}{l}78.81 \pm \\
1.49^{\mathrm{c}}\end{array}$ & $\begin{array}{l}6.87 \pm \\
0.31^{\mathbf{c}}\end{array}$ & $\begin{array}{l}52.24 \pm \\
1.61^{\text {c }} \\
\end{array}$ & $\begin{array}{l}2.76 \pm \\
0.37^{\mathbf{c}}\end{array}$ & $\begin{array}{l}0.058 \pm \\
0.019^{\mathrm{c}}\end{array}$ \\
\hline $\mathrm{HGC}+\mathbf{O 3}$ & $\begin{array}{l}13.22 \pm \\
0.63^{\mathrm{d}}\end{array}$ & $\begin{array}{l}68.92 \pm \\
1.71^{\mathrm{c}}\end{array}$ & $\begin{array}{l}5.71 \pm \\
0.32^{\mathbf{c}}\end{array}$ & $\begin{array}{l}46.11^{ \pm} \\
1.39^{\mathrm{d}}\end{array}$ & $\begin{array}{l}3.06 \pm \\
0.17^{\mathrm{d}}\end{array}$ & $\begin{array}{l}0.048 \pm \\
0.016^{\text {d }}\end{array}$ \\
\hline $\mathbf{H G C}+\mathbf{T}+\mathbf{O 3}$ & $\begin{array}{l}18.34 \pm \\
0.73^{\mathrm{e}}\end{array}$ & $\begin{array}{l}81.54 \pm \\
1.75^{\mathrm{d}}\end{array}$ & $\begin{array}{l}7.01 \pm \\
0.38^{\mathrm{d}}\end{array}$ & $\begin{array}{l}56.02 \pm \\
1.74^{\mathrm{e}}\end{array}$ & $\begin{array}{l}2.41 \pm \\
0.24^{\mathrm{e}}\end{array}$ & $\begin{array}{l}0.062^{ \pm} \\
0.015^{\mathrm{e}}\end{array}$ \\
\hline
\end{tabular}

- Values are expressed as mean $\pm \mathrm{SE}$

- a, b, c, d, e means with a common superscript within a column are not significantly different $(\mathrm{P}>0.05)$

$\mathrm{HGC}=$ rats with hepatogastrointestinal carcinoma

$\mathrm{HGC}+\mathrm{T}=$ rats with hepatogastrointestinal carcinoma plus taurine.

$\mathrm{HGC}+\mathrm{O} 3=$ rats with hepatogastrointestinal carcinoma plus oxygen molecules (Aquagen).

$\mathrm{HGC}+\mathrm{T}+\mathrm{O} 3=$ rats with hepatogastrointestinal carcinoma plus taurine and oxygen molecules (Aquagen).

$\mathrm{CEA}=$ Carcino-embryonic antigen $\quad \mathrm{AFP}=$ Alpha-fetoprotein $\quad \mathrm{CA}_{19.9}=$ Cancer antigen 19.9

$\mathrm{GSH}=$ Glutathione $\mathrm{GPx}=$ Glutathione peroxidase $\mathrm{CAT}=$ Catalase

$\mathrm{SOD}=$ Superoxide dismutase TBAR $=$ Thio barbutric acid reactive substrate. 
Table (3\&4): Effects of taurine, oxygen molecules (Aquagen) and their mixture on stomach intestine GSH and $\mathrm{TBAR}_{\mathrm{S}}$ contents and $\mathrm{Gp}_{\mathrm{X}}$ activity in rats with induced HGC

\begin{tabular}{|c|c|c|c|c|c|c|}
\hline \multirow[b]{2}{*}{ Groups } & \multicolumn{3}{|c|}{ Stomach } & \multicolumn{3}{|c|}{ Intestine } \\
\hline & $\begin{array}{l}\text { GSH } \\
\mathrm{mg} / \mathrm{g} \\
\text { tissue }\end{array}$ & $\begin{array}{c}\text { Gpx } \\
\text { nmol/mi/ } \\
\text { g protein }\end{array}$ & $\begin{array}{c}\mathbf{T B A R}_{\mathbf{S}} \\
\mathrm{nmol} / 100 \\
\mathrm{mg} \\
\text { protein }\end{array}$ & $\begin{array}{l}\text { GSH } \\
\mathrm{mg} / \mathrm{g} \\
\text { tissue }\end{array}$ & $\begin{array}{c}\text { Gpx } \\
\mu \mathrm{mol} / \mathrm{min} / \\
\mathrm{g} \text { protein }\end{array}$ & $\begin{array}{c}\text { TBAR } \\
\mathbf{s} \\
\mathrm{nmol} / \\
100 \mathrm{mg} \\
\text { protein }\end{array}$ \\
\hline Control & $\begin{array}{l}11.32 \pm \\
0.66^{\mathrm{a}}\end{array}$ & $\begin{array}{l}49.11 \pm \\
1.37^{\mathrm{a}}\end{array}$ & $\begin{array}{c}1.19 \pm \\
0.09^{\mathrm{a}}\end{array}$ & $\begin{array}{c}13.39 \pm \\
0.71^{\mathrm{a}}\end{array}$ & $\begin{array}{l}54.11 \pm \\
1.44^{\mathrm{a}}\end{array}$ & $\begin{array}{l}1.30 \pm \\
0.08^{\mathrm{a}}\end{array}$ \\
\hline HGC & $\begin{array}{c}6.51 \pm \\
0.36^{\mathbf{b}}\end{array}$ & $\begin{array}{l}27.81 \pm \\
0.92^{\mathbf{b}}\end{array}$ & $\begin{array}{c}2.18 \pm \\
0.17^{\mathbf{b}}\end{array}$ & $\begin{array}{c}8.35 \pm \\
0.42^{\mathbf{b}}\end{array}$ & $\begin{array}{l}36.79 \pm \\
1.14^{\mathbf{b}}\end{array}$ & $\begin{array}{c}2.91 \pm \\
0.27^{\mathbf{b}}\end{array}$ \\
\hline HGC + T & $\begin{array}{l}9.17 \pm \\
0.50^{\mathbf{c}}\end{array}$ & $\begin{array}{l}36.14^{ \pm} \\
1.27^{\mathrm{c}}\end{array}$ & $\begin{array}{l}1.62 \pm \\
0.13^{\mathbf{c}}\end{array}$ & $\begin{array}{c}10.59 \pm \\
0.56^{\mathbf{c}}\end{array}$ & $\begin{array}{l}44.44^{ \pm} \\
1.27^{\mathrm{c}}\end{array}$ & $\begin{array}{r}2.12 \pm \\
0.18^{\mathrm{c}}\end{array}$ \\
\hline $\mathrm{HGC}+\mathrm{O3}$ & $\begin{array}{c}7.92 \pm \\
0.41^{\mathrm{c}}\end{array}$ & $\begin{array}{l}31.69 \pm \\
1.71^{\mathbf{c}}\end{array}$ & $\begin{array}{l}1.84 \pm \\
0.12^{\mathrm{d}}\end{array}$ & $\begin{array}{r}9.66 \pm \\
0.61^{\mathbf{c}}\end{array}$ & $\begin{array}{l}40.52 \pm \\
1.24^{\mathbf{d}}\end{array}$ & $\begin{array}{l}1.97 \pm \\
0.16^{\mathrm{d}}\end{array}$ \\
\hline $\mathrm{HGC}+\mathrm{T}+\mathrm{O3}$ & $\begin{array}{c}10.42 \pm \\
0.57^{\mathrm{d}}\end{array}$ & $\begin{array}{l}41.09^{ \pm} \\
1.29^{\mathrm{d}}\end{array}$ & $\begin{array}{l}1.33 \pm \\
0.17^{\mathrm{e}}\end{array}$ & $\begin{array}{c}11.73^{ \pm} \\
0.62^{\mathrm{d}}\end{array}$ & $\begin{array}{l}49.06 \pm \\
1.18^{\mathrm{e}}\end{array}$ & $\begin{array}{l}1.45 \pm \\
0.12^{\mathrm{e}}\end{array}$ \\
\hline
\end{tabular}

- Values are expressed as mean $\pm \mathrm{SE}$

- a, b, c, d, e means with a common superscript within a column are not significantly different $(\mathrm{P}>0.05)$

$\mathrm{HGC}=$ rats with hepatogastrointestinal carcinoma

$\mathrm{HGC}+\mathrm{T}=$ rats with hepatogastrointestinal carcinoma plus taurine.

$\mathrm{HGC}+\mathrm{O} 3=$ rats with hepatogastrointestinal carcinoma plus oxygen molecules

$\mathrm{HGC}+\mathrm{T}+\mathrm{O} 3=$ rats with hepatogastrointestinal carcinoma plus taurine and oxygen molecules.

$\mathrm{CEA}=$ Carcino-embryonic antigen $\quad \mathrm{AFP}=$ Alpha-fetoprotein $\quad \mathrm{CA}_{19.9}=$ Cancer antigen 19.9

$\mathrm{GSH}=$ Glutathione $\mathrm{GPx}=$ Glutathione peroxidase $\mathrm{CAT}=$ Catalase

$\mathrm{SOD}=$ Superoxide dismutase $\mathrm{TBAR}=$ Thio barbutric acid reactive substrate.

\section{DISCUSSION}

Cancer is a leading cause of death, clinically, cancer is a large group of disease perhaps a hundred or more, that vary in age of onset, rate of growth, state of cellular differentiation, diagnosis, detectability, invasiveness, metastatic potential, response to treatment and prognosis $^{(32)}$. Moreover, hepatogastrointestinal cancer is one of the most common malignant neoplasms and a major cause of morbidity and mortality worldwide ${ }^{(33)}$.

In the present investigation, a significant elevation of CEA, AFP and CA19.9 levels occurred as a results of NED induced cancer in rats. CEA is a marker for colorectal, gastrointestinal, lung and breast carcinoma $^{(34)}$. As elevations of CEA may be associated with benign disease (i-e, false positive results) and also there is a number of tumors that do not produce CEA (i-e, false - negative results). The present, CEA testing alone is not 
considered a reliable screening tool ${ }^{(35)}$. So, AFP and CA19.9 were also determined in the present study to provide a wider tumor markers profile.

The tumor marker is a substance found in blood or tissues that may suggest the presence of a type of cancer. They are measured qualitatively or quantitatively by chemical, immunological or molecular biological methods to identify the progression of cancer and to evaluate the improvement as a result of surgery chemotherapy or radiotherapy ${ }^{(36)}$.

CEA is a marker for colorectal, ${ }^{(37)}$ gastrointestinal $^{(38)}$, lung and breast carcinoma ${ }^{(39)}$. The clinical application of CEA are mainly for monitoring of gastrointestinal cancer alone or in combination with CA $19.9^{(40)}$. Biological half-life of CEA is from 2 to 8 days $^{(39)}$.

AFP is a marker for hepatocellular and germ cell carcinoma .AFP may be increased in non-cancer liver diseases, such as hepatitis and cirrhosis and during pregnancy, but it declines at the end of pregnancy. Because of its relative small molecular size, AFP can pass through the glomerular basement membrane and so can be detected in urine. The biological half-life of AFP is approximately 5 days ${ }^{(39)}$. So, AFP is a good tumor marker for hepatocellular and germ cell (non seminoma) carcinoma. Kelsten et al. $^{(41)}$ reported that the estimation of AFP is useful for determining prognosis and in the monitoring of therapy for hepatocellular carcinoma.

CA19.9 is a marker for gastrointestinal carcinoma ${ }^{(\mathbf{4 2})}$. CA19.9 is synthesized by normal human pancreatic and biliary ductular cells and by gastric, colonic, endometrial and salivary epithelia. CA19.9 is a specific marker for both gastrointestinal and pancreatic carcinoma $^{(43)}$. The combined use of both CEA and CA19.9 markers is useful to detect or follow up these types of cancer ${ }^{(34)}$.

It has been postulated that free radicals are involved in both the initiation and promotion stages of carcinogenesis and their scavengers are probable inhibitors of both stages. It is generally accepted that abnormality of antioxidant enzymes must occur during carcinogenesis or in tumors. This has turned out to be the case, as compared with appropriate normal cell counterparts, tumor cells are found to have abnormal activities of antioxidant enzymes. It has been found that tumor cells are particularly low in superoxide dismutase (SOD) activity and catalase (CAT) activity ${ }^{(44,32)}$.

Moreover, it was reported that free radicals produced as a result of cancer induction with nitrosoamine compound led to a significant decrease of glutathione (GSH), glutathione peroxidase (GpX), superoxide dismutase (SOD) and catalase (CAT) in the erythrocyte and tissues such as liver, stomach and intestine ${ }^{(45,46,47,5,9)}$. These results are in harmony with those obtained in the present study (tables 1,2 \&3).

Taurine has been proposed to act as both direct and indirect antioxidant. Taurine protects against oxidative damage under many conditions, decreasing rates of malondialdehyde formation from membrane unsaturated lipids ${ }^{(\mathbf{4 8 , 4 9 )}}$. The authors explained 
protective action of taurine through inhibition of oxygen free radicals. In agreement, it was proved that free radicals can cause decrease in antioxidant defense of the body and so, cause tissue damage ${ }^{(\mathbf{5 0})}$.

Early studies have postulated that the protective action of taurine on oxidant-induced damages of tissue components including degradation of hyaluronic acid may be attributed to both its scavenging action on hypochloriate $(\mathrm{HOCl})$ and chloramine and the complex formation of taurine with $\mathrm{HOCl}$ or $\mathrm{NH} 2 \mathrm{Cl}$ without scavenging action on oxygen free radicals ${ }^{(51,52)}$.

The protective capacity of taurine was attributed to free radicals scavenging. Subjects treated with placebo showed a significant increase in the number of severely damaged mitochondria after reprefusion, whereas the number of damaged and necrotic myocytes also increased significantly in these subjects after infusion. No such damage to mitochondria or myocytes was observed in the taurine treated subjects $^{(\mathbf{5 1})}$. The use of supplemental taurine as a physiological protective against lipid peroxidation was advocated by Cardin,et $\mathrm{al}^{(\mathbf{5 2})}$ who demonstrated the protection of hamaster bronchioles from acute NO2-induced alterations. The authors outlined the mechanism of action of the acute ROS tissue damage is believed to act. $\mathrm{NO}_{2}$ and its highly ROS interact directly with plasma membrane of cell products, possibly via lipid peroxidation triggering a series of events that include the release of chemotactic factors and acute phase reactions responsible for the influx of neutrophils. Activation of neutrophils results in production of superoxide, free radicals and hydrogen peroxide $\left(\mathrm{H}_{2} \mathrm{O}_{2}\right)$, which cause further epithelial damage. Activated neutrophils also release proteolytic enzymes that have the capacity to alter alveolar interstitial components. Furthermore, the protective activity of taurine may reside in its ability to become chlorinated in the presence of $\mathrm{HOCL}^{(\mathbf{5 3 , 5 4})}$, thereby preventing the direct attack of this oxidant on cell membranes ${ }^{(\mathbf{5 5})}$.

In the current study, the cancer group of rats group treated with taurine after induction of cancer, showed a significant decrease in the level of all tumor markers (CEA, AFP and CA 19.9). These results may be due to the powerful effect of taurine to scavenge free radicals, lessen the lipid peroxidation and increase the immune system defense. These results confirm the results of Fukuda,et al. ${ }^{(56)}$.The authors suggested that taurine appeared to inhibit lipid peroxidation, to alter the activity of the defense enzyme system and to protect the liver and intestinal tract against membrane disintegration during rat hepatointestinal carcinogenesis. In addition, they reported that hepatic steatosis could be ameliorated by administration of taurine.

Likewise, taurine protects rats from lipid peroxidation (expressed in terms of malondialdehyde and conjugated dienes content) in the liver, brain and heart under acute severe normobaric hypoxia ${ }^{(57)}$. The mechanism of antioxdant action of taurine is due to the prevention of lactate accumulation in tissue and cell 
membrane structure disorders (expressed in a decrease of membrane $\mathrm{Na}+\mathrm{K}+$ ATPase activity). They also showed that taurine prevents the decrease of glutathione reductase and glutathione peroxidase activities in acute sever hypoxia. Moreover, taurine acts as an endogenous antioxidant and antifibrotic agents that prevents glucose induced lipid peroxidation and increased collagen production in cultured rat mesengial cells. Concomitantly, it was suggested that taurine inhibits lipid peroxidation and decreased serum triglyceride and low density lipoprotein cholesterol levels ${ }^{(\mathbf{5 8})}$.

Oxygen therapy (as used in alternative treatments) uses one or more chemicals that are supposed to release oxygen after they are introduced into the body. Two of the most common compounds used in oxygen therapy are ozone (a chemically active form of oxygen) and hydrogen peroxide. This type of treatment with oxygen-releasing substances is different from the common medical uses of oxygen, which involve increasing the amount of oxygen in inhaled air. It is also different from hyperbaric oxygen, which involves the use of pressurized oxygen $^{(59)}$.

Oxygen molecules (Aquagen) are highly beneficial for either healthy or sickly people. It is easy to consumed regularly. Besides providing more oxygen to the brain (greater alertness and mental clarity), oxygen molecules (Aquagen) will oxidize pathogens and synthetics residues in the body, allowing their complete elimination through excretion ${ }^{(60)}$.
There are many clinical and anecdotal reported that oxygen therapy was considered as a major or minor auto therapy, at times prescribed on a daily basis for several weeks applied to the treatment of various carcinomatous conditions but with a paucity of controlled data. ${ }^{(61)}$ Several researchers have focused their efforts on using oxygen therapy as an adjunct to radiation or chemotherapy $^{(17)}$.

In the current study (Table 1, 2 \& $3)$, the cancer group of rats treated with oxygen molecules (Aquagen) after induction of cancer, a significant decrease occurred in the level of all tumor markers (CEA, AFP and CA 19.9) and TBARS levels, and a significant improvement in the activities of glutathione (GSH), glutathione peroxidase (GpX), superoxide dismutase (SOD) and catalase (CAT) in the erythrocyte and tissues such as liver, stomach and intestine. These results could be attributed to the physical and chemical characteristic power effect of oxygen molecules (Aquagen) which could stop cancer from spreading and start killing existing cancer cells, rebuild the immune system and damaged tissue, so the body can naturally transform or expel any tumorous masses and eliminate the causal factors that destroyed immune system in the first place. Some authors ${ }^{(59,60)}$ explained the benefits of cancer treatment with oxygen molecules (Aquagen) to it's ability as a super cellular hydration and revitalization, an increased oxygenation at the cellular level, an enhanced nutrient absorption \& removal of metabolic wastes, an activation of enzymes, 
immune system support and greater metabolic balance, an enhanced endurance and reduced recovery time from strenuous exercise, an electronrich free-radical neutralization .

Moreover, in cancer patients, the administration of low concentrations of oxygen molecules (Aquagen) have been proven to increase alpha interferon. Interferon is an anti-cancer substance that laboratories all over the world are trying to reproduce, but with oxygen molecules (Aquagen), the body will make its own. Once interferon production is initiated, interleuken-2, another anti-cancer agent, is increased. This sets in motion a cascade of immunological events. Specifically, tumor necrosis factor, macrophages, and phagocytes increase, and immunoglobulin processes, such as $\operatorname{IgA}$, IgE, and IgM, activity $^{(62)}$.

In conclusion, the present investigation was designed to investigate the possible chemopreventive role of taurine or/and oxygen therapy by assessing their antioxidant properties with respect to lipid peroxidation and antioxidant system, against NED induced hepatogastrointestinal carcinogenesis in rats.

\section{REFERENCES}

1. Ruddon, R.W. (1995): Cancer Biology. $\quad 3^{\text {rd }}$ ed. Oxford University Press.

2. Fiedler, I.J. and Hart, I.R. (1982): Biologic diversity in metastatic neoplasms-origins and implications. Science, 217:9981002.
3. Ames, B.N. and Hagen, T.M. (1993): Oxidants, antioxidants and the degenerative diseases of aging. Proc. Natl. Acd. Sci. U.S.A. 90:7915

4. Fraumeni, J.F.; Devesa, S.S.; Hoover, R.N. and Kinlen, L.J. (1993): Epidemiology of Cancer: In Cancer Principles and Practic of Oncology. Devita, V.T.; Hellman, S. and Rosenberg, S.A. Eds. Lippin Cott. Philadelphia. U.S.A. 150.

5. Thirunavukkarasu, C. and Sakthisekaran, D. (2001): Effect of selenium on Nnitrosodiethylamine-induced multistage hepatocarcinogenesis with reference to lipid peroxidation and enzymatic antioxidant. Cell Biochemistry and Function, 19-27-35.

6. Bakshwan, S.A. (2004): Antitumor effects of vitamin E, coenzyme Q 10 , garlic oil or their mixture on MNNG induced carcinogenesis in male albino rats. J. Egypt. Ger. Soc. Zool., 45 (A): 263-280.

7. El-Negmy, F.A. (2005): Prophylactic action of taurine against the carcinogenic effect of N-methyl-N'-nitro Nnitrosoguandine (MNNG) on hepatogastrointestinal tract of male albino rat. Egypt J.Basic and Appl. Physiol., 4(1).

8. Heibashy, M.I.A. and BadieBakshwan, S.A. (2006): Alterations in cytochrome P 450 and drug metabolizing enzymes as a result of induction of hepatocolon cancer in mice. J. Egypt Ger. Soc. Zool., 51(A):469-485. 
9. Heibashy, M.I.A. and Mazen, G.M.A. (2008): Chemoprevention of tea polyphenols against tumor growth of hepatocolon cancer induced by azoxymethane in rats. Egyptian Soc. Nucl. Sci. Appl., Under Arab J. Nucl. Sci. Appl.41 (1) :261-270.

10. Heibashy, M.I.A. (2005): Effect of vanadium and taurine on lipid profile and some parameters indicative of myocardial status in male rats with streptozotocin induced diabetes J. Egypt. Ger. Soc. Zool., 47(A): 117- 138.

11. Nishikawa, A.; Tanakamaru, Z.Y. and Furukawa, F. (1998): Chemopreventive activity of oltipraz against induction of glandular stomach carcinogenesis in rats by N-methyl-N'-nitro-Nnitrosoguandine. Carcinogenesis, 19(2): 365-368.

12. Pasantes-Morales, H.; Quesada, O. and Moran, J. (1998): Taurine: An osmolyte in mammalian tissues. Adv. Exp. Med. Biol., 442:209-217.

13. Huxtable, R. (1992): Physiological action of taurine. Physiol. Rev., 72:101-163.

14. Kuriyama, K. (1980): Taurine as neuromodulator. Fed. Proc., 39:2680-2684.

15. Wright, C.E.; Tallan, H.H. and Lin, Y.Y. (1986): Taurine biological update. Ann. Rev. Biochem., 55:417-453.

16. Watson, R.G.W.; Kemond, H.P. and Bouchier-Hayes,D. (1994): Taurine upregulates antimicrobial function of human inflammatory cells. Surg. Forum, 45:679-681.
17. Tietz, C. (1983): Ozontherapie als adjuvans in der onkologie. Ozo Nachrichten;2:4.

18. Leon OS, Menendez S, Merino N, Castillo R, Sam S, Perez L, ET AL.: Ozone oxidative preconditioning : a protection against cellular damage by free radicals. Mediators Inflamm. 1998; 7: 289-294.

19. Clavo B, Perez JL, Lopez L, Suarez G, Lloret M, Rodriguez V, et al.: Effect of ozone therapy on muscle oxygenation. J, Altern, Complement Med. 2003;9:251256.

20. Sweet J, Kao MS, Lee D, Hagar W: Ozone selectively inhibits growth of human cancer cells. Science 1980;209:931-933.

21. Giunta R, Coppola A, Luongo C, Sammartino A, Guastafierro S, Grassia A, et al.: Ozonized autohemotransfusion improves hemorheological parameters and oxygen delivery to tissues in patients with peripheral occlusive arterial disease. Ann Hematol. 2001;80:745-748.

22. NRC National Research Counal (1977): Nutrient Requirements of Domestic Animals, Nutrient Requirements of Rat. National Academy of Science, Washington, DC, U.S.A.

23. Yoshiji, H.; Nakae, D.; Kinugasa, T. ; Matsuzaki, M. ; Denda, A. and Suiji, T. (1991): Inhibitory effect of the iron deficiency on the induction of putative preneoplastic foci in rat liver initiated with diethyllnitrosamine and promoted by phenobarbital. Be. J. Cancer, 64: 839 - 842. 
24. Ellman, G.L. (1959): Tissue sulfhydryl groups. Arch. Biochem. Biophys., 82 : $70-77$.

25. Rotruk, J.T.; Pope, A.L.; Ganther, H.E.; Swanson, A.B. ;Hafeman, D.G. and Hoekstra, W(1973): Selenium: Biochemical roles as a component of glutathione peroxidase. Science, 179: 588-590.

26. Oyanagui, Y. (1984): Evaluation of assay methods and establishment of kit for superoxide dismutase. Anal. Biochem., 142 : 290 - 296.

27. Sinha, A.K. (1972): Colorimetric assay of catalase. Anal. Biochem., 47 : 389 - 394.

28. Hogberg, J.; Larson, R.E.; Kristoferson, A. and Orrenius, S. (1974): NADPH-dependent reductase solubilised from microsomes by peroxidation and its activity. Biochem. Biophys. Res. Commun., 56 : 836 - 842.

29. Devasagayam, T.P.A. and Tarachand, V. (1987): Decreased lipid peroxidation in the rat kidney during gestation. Biochem. Biophys. Res. Commun., 145: 134 - 138.

30. Mc Lean, A.E.M. and Day, P.A. (1974): The use of new methods to measure: The effect of diet and inducers of microsomal enzyme synthesis on cytochrome P450 in liver hormogenates and on metabolism of dimethylnitrosamine. Biochem. Pharm., 23:1173-1180.

31. Snedecor, G.W. and Cochran, W.G. (1982): "Statistical Methods" $7^{\text {th }}$ ed. Two State University press, Ames Iowa, U.S.A.
32. Kelsen, D.P.; Daly, J.M.; Levin, B.; Kern, S.E. and Tepper, J.E. (2002): Gastrointestinal Oncology: Principles and Practice. $2^{\text {nd }}$ ed. Lippincott Williams and Wilkins, A Wolters Kluwer Company, Philadelphia, Baltimore, New York, London, Buenos Aires. Hong Kong Sydney Tokyo.

33. Gore, R.M. (1997): Gastric cancer: Clinical and pathological features. Radiol. Clin. North. Am., 35 : 295 - 310.

34. Daniel, W.C.; Mc-Lean, A. and Thomas, G. (2002): Tumor Markers. $5^{\text {th }}$ ed. Lang Medical Publication Less, Atlas, California, U.S.A.

35. Sikorska, H.M.; Fuks, A. and Gold, $\quad$ P. (1992): Carcinoembryonic Antigen. In: Serological Cancer Markers. S. Sell, S. Ed. Totowa, NJ, the Humana Press,47 - 97.

36. Chan, D.W. and Sell, S. (2001): Tumor Markers. In Tietz fundamentals of clinical chemistry. Burtis, C.A. and Ashwood, E.R. Eds. W.B Saunders Company. U.S.A 390413.

37. Forones, N.M. and Tanaka, M. (1999): CEA and CA 19.9 as prognostic indices in colorectal cancer. Hepatogastroenterology, 46(26): 905-908.

38. Carpelon-Holmstrom, M.; Louhimo, J.; Stenman, U-H.; Alfthan, H. and Haglund, C. (2002): CEA, CA 19.9 and CA 72.4 improve the diagnostic accuracy in gastrointestinal cancer. Anticancer Res., 22 (4):2311-2316. 
39. Khalifa, A.M.D. (1990): Tumor Markers. In Clinical Chemical Pathology and Applied Hematology. Khalifa, A. Ed. University Book House. Cairo. Egypt., 220-243.

40. Louhimo, J.; Finne, P.; Alfthan, H.; Steman, U.H. and Haglund, C. (2002): Combination of HCG beta, CA 19.9 and CEA with logistic regression improves accuracy in gastrointestinal malignancies. Anticancer Res., 22(3):1759-1764.

41. Kelsten, M.L.; Chan, D.W. and Bruzek, R.C. (1988): Monitoring hepatocellular carcinoma, a monoclonal immunoenzymometric assay for alphafetoprotein. Clin. Chem., 34:76 81.

42. Marrelli. D.; Pinto, E.; Destefano, A. and Garosi, L. (2001): Clinical utility of CEA, CA 19.9 and CA 72.4 in the follow up of patients with resectable gastric cancer. Am. J. Surg., 181:9-16.

43. Lamerz, R. (1992): CA19.9: GICA (gastrointestinal cancer antigen): In : Serological Cancer Markers. Sell, S. Ed. Totowa, NJ, the Humana Press, 309-339.

44. Heibashy, M.I.A. and Hegazy, H.G. (2002): Effect of dietary mrthionine and iron contents on the antioxidant defence system, iron adequacy status and lipid profile in rats. Egypt J. Zool., 39: 47-62

45. Diplock, A.T.; Rice-Evans, C.A. and Burdon, R.H. (1994): Is there a significant role for lipid peroxidation in the causation of malignancy and for antioxidants in cancer prevention? Cancer Res., 54: 1952 $-1956_{\mathrm{S}}$.

46. Arivazhagan, S.; Balasenthil, S. and Nagini, S. $\left(\mathbf{2 0 0 0}_{\mathrm{a}}\right)$ : Modulatory effects of garlic and neem leaf extracts on N-methylN-nitro-N-nitrosoguanidine (MNNG) induced oxidative stress in Wister rats. Cell Biochem. Funct., $18: 17-21$.

47. Arivazhagan, S.; Balasenthil, S. and Nagini, S. $\left(\mathbf{2 0 0 0}_{\mathrm{b}}\right)$ : Garlic and neem leaf extracts enhance hepatic glutathione and glutathione dependent enzymes during N-methyl-Ń-nitro-Nnitrosoguanidine (MNNG) induced gastric carcinogenesis in rats. Phytother. Res., 14:291293.

48. Kaira, J.; Mantha, S. and Prasad, K. (1994): Oxygen free radicals: key factors in clinical disease. Lab. Med. International, 1:16-9.

49. Heibashy, M.I.A. and Amer, M.M. (2003): Assessment of the therapeutic role of taurine, vitamin $\mathrm{E}$ and selenium on copper induced liver and kidney dysfunction in albino rats. J. Egypt. Ger. Soc. Zool, 42(A):353-371.

50. Terry, P.; Lagergrenj,; YE.; W.; Nyren, O. and Wolk, A. (2000): Antioxidants and cancers of the esophagus and gastric cardia. Int. J. Cancer, 87(5):750 754.

51. Lee, C.; Lee, K.Y.; Adlee, K. (1992): Inhibitory effect of taurine on $\mathrm{HOCl}$ and $\mathrm{NH}_{2} \mathrm{Cl}$ induced degradation of hyaluronic acid. Korean J. Pharmacol., 28(2):201-212. 
52. Cardin, V.; Segura, C.and pasants-Morales, H. (1999): Activation and inactivation of taurine efflux in hyposomatic and isosomatic swelling in centrial astrocytes: Role of ionic strength and cell volume decrease. Neurosci. Res., 56(6):659-667.

53. Heibashy, M.I.A. (2000): Hypolipidemic effect of taurine and L-carinitine on rats fed a high cholesterol diet. J.Union Arab. Biol., Cairo, 8-11.

54. Gordon, R.; Shaked, A. and Solana, D. (1986): Taurine portects hamaster bronchioles from acute NO2-induced alteration. Am. J. Pathol., 125: 585-600.

55. Rock, C.L.; Jacob, R.A. and Bowen, P.W. (1996): Updata on the biological characteristics of the antioxidant micronutrients: vitamin $C$, vitamin $\mathrm{E}$ and the carotenoids. J.Am. Diet. Ass., 96 (7) $32-38$

56. Fukuda, T.; Ikejima, K.; Hirose, M.and Sato. N. (2000): Taurine presence gap junctional intracellular communication in rat hepatocytes under oxidative stress. J. Gastroenterol, 35 (5): 361-368.

57. Man 'Kovs 'Ka, I.; Vavilova, M.and Bystriukou, U. (1998): The antioxidant action of taurine in acute hypoxia. Fizol-zh., 44(56):137-189.

58. Trachtman, H.; Futterweit, S.and Robert, S. (1993): Taurine prevents glucose-induced lipid peroxidation and increased collagen production in cultured rat mesangial cells. Biochemical and Biophysical Research Communication, 191:759-756.

59. Bocci V.: Does ozone therapy normalize the cellular redox balance? Implications for therapy of human immunodeficiency virus infection and several other diseases. Med, Hypotheses. 1996;46:150-154.

60. Kelleher DK, Hummel M, Vaupel P. Lack of tumor oxygenation improvement upon ozone therapy in experimental tumors. Strahlenther Onkol. 2000; 176: 115 .

61. Viebahn R: The biochemical process underlying ozone therapy. Ozo Nachrichten 1985; 4:4:18-30.

62. Peralta C, Leon OS, Xaus C, Prats N, Jalil EC, Planell ES, et al.: Protective effect of ozone treatment on the injury associated with hepatic ischemiareperfusion: antioxidantprooxidant balance. Free Radic, Res. 1999; 31:191-196. 
دور كل من التاورين والعلاج بالأكسجين وخليطهما معا كعامل مضاد للسر طان

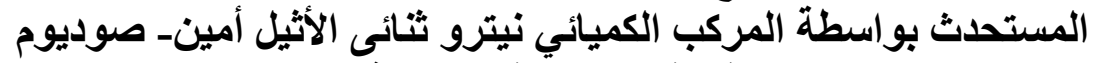
في ذكور الجرذان البالغة فئة البئ

محد أسلام أحدد حبيشي و* ولاء أحمد مصطفي النحراوي

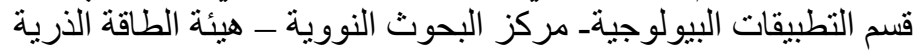

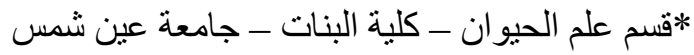

$$
\text { ملخص البحث }
$$

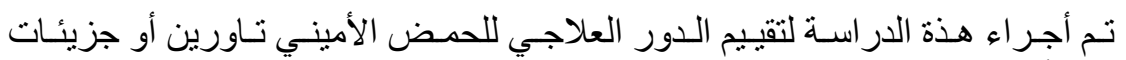

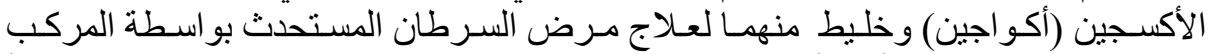

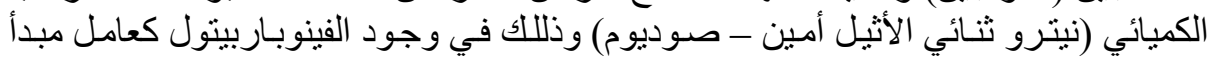
لمرض السرطان في ذكور الجرذان.

كنتيجة أستحداث مرض السرطان في ذكور الجرذان الجران حدث أرتفاع معنوي في دلائل

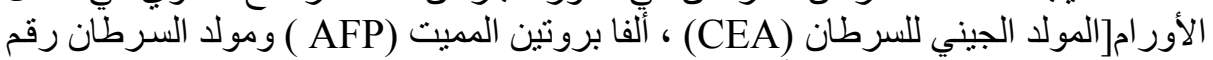

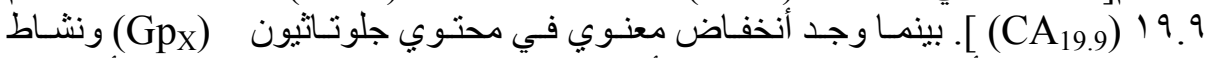

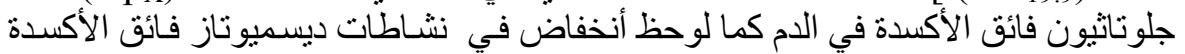

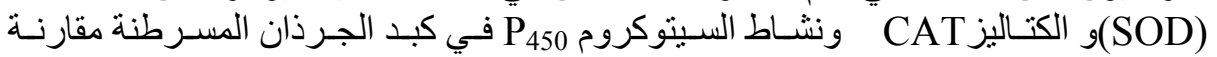
بالجرذان الضابطة.

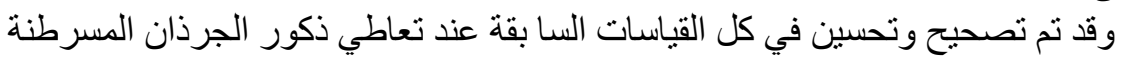

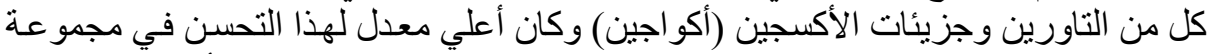

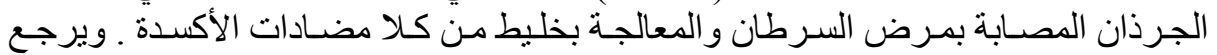

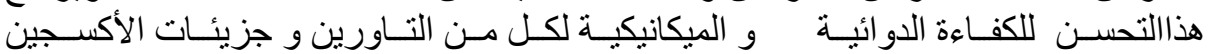

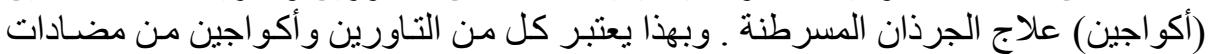
السرطان المستحدث في ذكور الجرذان. 